\title{
Long-term Exposure to Acetaminophen is a Crucial for Activity of Selected Antioxidative Enzymes and Level of Lipid Peroxidation Process in Rat Liver
}

Renata Polaniak ${ }^{1}$, Rafał Jakub Bułdak²*, Wojciech Jacheć ${ }^{3}$, Krzysztof Helewski ${ }^{4}$ Romuald Wojnicz ${ }^{4}$, Ewa Birkner ${ }^{1}$, Michał Kukla², Marcin Gowarzewski $^{2}$, Robert Kubina ${ }^{5}$ and Krystyna Żwirska-Korczala ${ }^{2}$

${ }^{1}$ Department of General Biochemistry, Silesian Medicine University, Poland

${ }^{2}$ Department of Physiology, Silesian Medicine University, Poland

${ }^{3}$ 2nd Department of Cardiology, Silesian Medicine University, Poland

${ }^{4}$ Department of Histology, Silesian Medicine University, Poland

${ }^{5}$ Department of Pathology, Silesian Medicine University, Poland

\begin{abstract}
Background: Our aim was to investigate the effect of intra-oesophageal acetaminophen instillation on the selected antioxidative enzymes activity: superoxide dismutase isoenzymes (MnSOD, Cu/ZnSOD), glutathione peroxidase (GPX), glutathione-S-transferase (GST), glutathione reductase (GR) and lipid peroxidation in rat liver after 4,8 and 12 weeks of exposure.

Material and methods: Male Wistar FL strain rats weighing 150-160 g were treated with paracetamol by intraoesophageal instillation at a dose of $2.4 \mathrm{~g} / \mathrm{kg} \mathrm{b} . w$ every day up to 12 weeks. During the whole experiment rats were kept in a night-and-day's cycle lasting twelve hours, with standard feed ad libitum. Rats were sacrificed after 4, 8 and 12 weeks of the study. The collected tissue liver was homogenized and the above mentioned enzymes were determined in the supernatants.

Results: The current study revealed the presence of paracetamol-induced changes in the activities of antioxidative enzymes in comparison to the control values. Our results suggested that long term exposure to PC (8 and 12 weeks) decreased activity of GPX enzyme and increased activity of GST and GR enzymes as well as increased level of lipid peroxidation process in rat liver. These changes in the activity of antioxidative enzymes may be involved in paracetamol toxicity of the liver after a longer time of exposure to PC. The cited literature and our findings show that excessive use of paracetamol-containing preparations can have a harmful effect upon liver metabolism and suggest the need for further research.
\end{abstract}

Keywords: Acetaminophen; Antioxidative enzymes; Lipid peroxidation; Rat liver

\section{Introduction}

Metabolism of mammals is subjected to permanent modulations, with the essential role played by the change in enzymatic activity due to different factors, e.g. drugs. Recently, it has been proved that paracetamol (acetaminophen, PC), an antipyretic and analgesic drug administered chronically in large doses, induces hepatotoxic activity [1-5].

Paracetamol is well absorbed from the gastrointestinal tract and it relatively poorly binds to blood proteins (20-50\%). A part of the ingested drug dose is coupled in liver with glucuronic acid (60\%), active sulfonic acid or glycine, and excreted with urine in the form of such compounds [6-8].

The remaining part of paracetamol is metabolised by cytochrome $\mathrm{P}-450$ in liver to a non-toxic catechol and toxically acting $\mathrm{N}$-acetylp-bensoquinone-imine (NAPQI), which injures hepatocytes. Accumulation of this metabolite can lead to liver necrosis [4,9]. NAPQI is coupled with glutathione in the presence of glutathione-S-transferase $[10,11]$. NAPQI is an inhibitor of the respiratory chain complex. As a result of its activity, even $90 \%$ decrease in the ATP (adenosine triphosphate) production can be demonstrated in hepatic mitochondria. Furthermore, during paracetamol oxidation to a quinone form, freeradicals can be produced. As a consequence, damage to mitochondria and cell death can occur $[3,12,14,15]$. Mitochondria are thought to be primary targets in acetaminophen toxicity with particular attention on the mitochondrial permeability transition [7]. Generation of reactive oxygen species such as nitric oxide and superoxide anion may be important determinants in hepatocytes death [7-9].

In the view of literature data, there are contradictory reports on the involvement of free-radicals in the pathomechanism of paracetamol toxic action. Our aim was to investigate the effect of intra-oesophageal acetaminophen instillation on the selected antioxidative enzymes activity: superoxide dismutase isoenzymes (MnSOD, Cu/ZnSOD), glutathione peroxidase (GPX), glutathione-S-transferase (GST), glutathione reductase (GR) and lipid peroxidation in rat liver after 4,8 and 12 weeks of exposure.

*Corresponding author: Dr. Rafał Jakub Bułdak, Department of Physiology, Silesian Medicine University; Jordana St. 19, 41-808 Zabrze, Poland, Tel/Fax +48/32/272-23-72; E-mail: rbuldak@sum.edu.pl

Received August 04, 2011; Accepted September 10, 2011; Published September 12, 2011

Citation: Polaniak R, Bułdak RJ, Jacheć W, Helewski K, Wojnicz R, et al. (2011) Long-term Exposure to Acetaminophen is a Crucial for Activity of Selected Antioxidative Enzymes and Level of Lipid Peroxidation Process in Rat Liver. J Bioequiv Availab 3: 182-186. doi:10.4172/jbb.1000082

Copyright: (c) 2011 Polaniak R, et al. This is an open-access article distributed under the terms of the Creative Commons Attribution License, which permits unrestricted use, distribution, and reproduction in any medium, provided the original author and source are credited. 
Citation: Polaniak R, Bułdak RJ, Jacheć W, Helewski K, Wojnicz R, et al. (2011) Long-term Exposure to Acetaminophen is a Crucial for Activity of Selected Antioxidative Enzymes and Level of Lipid Peroxidation Process in Rat Liver. J Bioequiv Availab 3: 182-186. doi:10.4172/ jbb.1000082

\section{Materials and Methods}

\section{Animals}

Tests were carried in 60 male rats from inbred Wistar FL strain, with the initial body weight of $150 \mathrm{~g}( \pm 11)$. The animals originated from the Central Animal Facility at the Silesian Medicine University. After being transported to the department animal facility, they underwent adaptation for three weeks. During the whole experiment rats were kept in a night-and-day's cycle lasting twelve hours, with standard feed ad libitum. The rat diet contained 23\% crude protein, $5 \%$ ether extract, $4 \%$ crude fiber, $8 \%$ ash, $1.2 \%$ calcium, $0.6 \%$ phosphorus, $54 \%$ nitrogen-free extract and $3600 \mathrm{kcal} / \mathrm{kg}$ metabolizable energy. The metal contents $(\mathrm{mg} / \mathrm{kg}$ dry weight) of the rat diet were: copper 10, zinc 45 , manganese 55, cobalt 5 and iron 75. Animals were maintained under standard management conditions and handled as per the Animal Ethics Guidelines of Medical University of Silesia in Poland.

\section{Chemicals and dose/concentration selection}

Acetaminophen (99\% purity) was obtained from Sigma-Aldrich (St. Louis, MO). Acetaminophen was dissolved in pathogen-free phosphate buffered saline (x1) without $\mathrm{Mg}^{2+}, \mathrm{Ca}^{2+}$ ions (Sigma-Aldrich, St.Louis, $\mathrm{MO})$. Acetaminophen was administered in an hepatotoxic dose of $2.4 \mathrm{~g} / \mathrm{kg}$ of body weight $/ 24 \mathrm{hrs}$ (i.e. $16 \mu \mathrm{mol} / \mathrm{kg}$ of body weight $/ 24 \mathrm{hrs}$ ) as determined in our preliminary study. The maximum permissible daily dose of acetaminophen for adults is $4000 \mathrm{mg}$. For a $60-\mathrm{kg}$ man, it becomes $66.67 \mathrm{mg} / \mathrm{kg}$ b.w., whose dose equivalent for rat (66.67 x 6.3) is $420 \mathrm{mg} / \mathrm{kg}$ b.w. according to van Miert [13]. The dose equivalent per $\mathrm{kg}$ for rat (x 6.3) was derived by dividing the $\mathrm{K}_{\mathrm{m}}$ factor [body surface area $\left(\mathrm{m}^{2}\right)$ to body weight $(\mathrm{kg})$ ratio] for humans with the $\mathrm{K}_{\mathrm{m}}$ factor for rat species. In the current study, almost 6 times of this dose equivalent, i.e., $2.4 \mathrm{~g} / \mathrm{kg}$ b.w $/ 24$ hours was used. The paracetamol dose used in the research was established during a pilot study and was based on the above described assumptions. It caused essential changes in the activity of antioxidative enzymes in the rat liver homogenates.

\section{Experimental design and preparation of liver homogenate}

Within the experiment, all animals were divided into two groups: Group 1; control group (C) - animals drank water ad libitum. Group 2; study group (B) - rats were given paracetamol (acetaminophen) solution by intra-oesophageal instillation in a dose of $2.4 \mathrm{~g} / \mathrm{kg}$ of body weight $/ 24 \mathrm{hrs}$ (i.e. $16 \mu \mathrm{mol} / \mathrm{kg}$ of body weight $/ 24 \mathrm{hrs}$ ), after drinking it, they had unlimited access to distilled water. Instillation of the established paracetamol dose was done with use of a sterile one-way, intra-oesophageal catheter (probe) made from soft silicon, connected with a syringe filled with paracetamol solution, having above stated concentration in the volume $(1 \mathrm{ml})$. Rats were sacrificed after 4,8 and 12 weeks, the collected livers were homogenized in a Potter-Elvehjem homogenizer (a teflon/glass system) to pool the collected material. A $200 \mathrm{mg}$ of liver sample was taken in $2 \mathrm{ml}$ of ice-cold $50 \mathrm{mM}$ potassium phosphate buffer ( $\mathrm{pH} 7.4$ ) containing 1mM EDTA. The homogenates $(10 \%)$ were then centrifuged at $12000 \times g$ for $15 \mathrm{~min}$ at $4^{\circ} \mathrm{C}$. The supernatants were separated and used for enzyme activities assays and protein determination.

\section{Measurement of selected antioxidative enzyme activities in} rat liver

SOD isoenzymes assay: Superoxide dismutase isoenzymes (MnSOD, Cu/ZnSOD) activity was assayed using the method of Oyanagui [16]. For the determination of MnSOD activity, Cu/ZnSOD was inhibited by incubating samples with $5 \mathrm{mM}$ sodium cyanide for 30 min with samples assayed for activity within $2 \mathrm{~h}$ of adding cyanide to sample mixture. Total specific SOD activity and that of MnSOD (after $\mathrm{Cu} / \mathrm{ZnSOD}$ inhibition with $\mathrm{KCN}$ ) was measured, and then the $\mathrm{Cu} / \mathrm{ZnSOD}$ activity was calculated. The enzymatic activity of both SOD isoenzymes was expressed in Nitric Units (NU) per milligram of protein (NU/mg p.); $1 \mathrm{NU}$ represents $50 \%$ inhibition by SOD of the nitrosol ion formation under the conditions of the method.

GPX activity assay: Glutathione peroxidase (GPX) activity was assayed by the coupled enzyme assay of Paglia and Valentine [17]. Consumption of $0.2 \mathrm{mM} \mathrm{NADPH}$ was followed in media containing $50 \mathrm{mM}$ potassium phosphate buffer ( $\mathrm{pH}$ 7.4), $1 \mathrm{mM}$ EDTA, $1 \mathrm{mM}$ sodium azide, $10 \mathrm{mM}$ GSH, $5 \mathrm{U}$ of glutathione reductase and $20 \mu \mathrm{l}$ of the enzyme extract. Activity of GPX was measured by initiating the reaction with $2.4 \mathrm{mM}$ cumene hydroperoxide. The activity of GPX has been determined as the number of micromoles of NADPH used for the regeneration of GSH within 1 min at $25^{\circ} \mathrm{C}$, recalculated per gram of protein (IU/g protein).

GST activity assay: The enzyme activity of GST was estimated in liver homogenate following the rate of increase in optical density at 340 $\mathrm{nm}\left(25^{\circ} \mathrm{C}\right)$ due to formation of 1-chloro-2, 4-dinitrobenzene (CDNB) conjugate of GSH acc. to Habig's et al. method [18]. The activity of GST has been presented as IU per gram of protein.

GR activity assay: Glutathione reductase (GR) was also assayed by the kinetic method acc. to Richterich's protocol [19] by monitoring the oxidation of NADPH at $340 \mathrm{~nm}$ The activity of GR was determined as the quantity of micromoles of $\mathrm{NADPH}^{+} \mathrm{H}^{+}$used to recover $\mathrm{GSH}$ in 1 min converted to gram of protein (IU/g protein).

\section{Determination of malondialdehyde (MDA) level}

Liver lipid peroxidation was determined by measuring the level of MDA according to the method of Ohkawa et al. [20] with minor modifications. Two hundred microliters of tissue homogenate was added to $100 \mu \mathrm{l}$ of $8.1 \%$ sodium dodecyl sulfate, vortexed and incubated for $10 \mathrm{~min}$ at room temperature. Six hundred and seventyfive microliters of $20 \%$ acetic acid and $750 \mu \mathrm{l}$ of thiobarbituric acid $(0.6$ $\%$ ) were added and placed in a boiling water bath in sealed tubes for 60 min. The samples were allowed to cool at room temperature. The 1.25 $\mathrm{ml}$ of butanol:pyridine (15:1) was added, vortexed and centrifuged at $2000 \times g$ for $5 \mathrm{~min}$. Five hundred microliters of the colored pink layer was measured at $532 \mathrm{~nm}$ on a spectrophotometer using 1,1,3,3-tetraethoxypropane as standard. MDA concentration was expressed as $\mu \mathrm{mol} \mathrm{MDA} / \mathrm{g}$ protein.

\section{Protein assay}

The total protein content in liver homogenate was estimated by the method of Lowry et al. [21] using bovine serum albumin as the standard.

\section{Statistical analysis}

The obtained results are presented in Table 1 and Table 2 as means (median) \pm SEM. For comparing the results Student's t-test or Mann Whitney $U$ test were used. Differences with $\mathrm{p}<0,05$ or $\mathrm{p}<0.001$ were considered as significant.

\section{Results}

Effect of acetaminophen treatment on SOD, GPX, GST as well as GR activity and MDA concentrations were studied as a function 
Citation: Polaniak R, Bułdak RJ, Jacheć W, Helewski K, Wojnicz R, et al. (2011) Long-term Exposure to Acetaminophen is a Crucial for Activity of Selected Antioxidative Enzymes and Level of Lipid Peroxidation Process in Rat Liver. J Bioequiv Availab 3: 182-186. doi:10.4172/ jbb.1000082

\begin{tabular}{|c|c|c|c|c|c|c|}
\hline Exposure times of PC & Groups & $\begin{array}{l}\text { Activity of MnSOD } \\
\text { [NU/mg. p] }\end{array}$ & $\begin{array}{l}\text { Activity of Cu/ZnSOD } \\
\text { [NU/mg. p] }\end{array}$ & $\begin{array}{l}\text { Activity of GPX } \\
\text { [IU/g.p] }\end{array}$ & $\begin{array}{c}\text { Activity of GST } \\
\text { [IU/g.p] }\end{array}$ & $\begin{array}{c}\text { Activity of GR } \\
\text { [IU/g.p] }\end{array}$ \\
\hline 4 weeks & $\begin{array}{l}\mathrm{C} \\
\mathrm{B}\end{array}$ & $\begin{array}{l}15744 \pm 987 \\
12472 \pm 738\end{array}$ & $\begin{array}{l}54575 \pm 1543 \\
50989 \pm 1383^{a}\end{array}$ & $\begin{array}{l}758 \pm 93,6 \\
699 \pm 66,7\end{array}$ & $\begin{array}{c}509 \pm 57,7 \\
558 \pm 92,8^{a}\end{array}$ & $\begin{array}{c}47 \pm 4.14 \\
58,6 \pm 8.28^{a}\end{array}$ \\
\hline 8 weeks & $\begin{array}{l}\text { C } \\
B\end{array}$ & $\begin{array}{l}21505 \pm 423 \\
19414 \pm 818^{b}\end{array}$ & $\begin{array}{l}48871 \pm 8132 \\
49184 \pm 9196\end{array}$ & $\begin{array}{l}378 \pm 69,3 \\
80 \pm 17,5^{b}\end{array}$ & $\begin{array}{c}412 \pm 62.7 \\
804 \pm 61^{b}\end{array}$ & $\begin{array}{c}37 \pm 4.16 \\
49.5 \pm 10.4^{\mathrm{a}}\end{array}$ \\
\hline 12 weeks & $\begin{array}{l}\mathrm{C} \\
\mathrm{B}\end{array}$ & $\begin{array}{c}15442 \pm 523 \\
10600 \pm 790^{b}\end{array}$ & $\begin{array}{l}45071 \pm 2449 \\
39664 \pm 1058^{a}\end{array}$ & $\begin{array}{l}311 \pm 5.2 \\
102 \pm 8.1^{b}\end{array}$ & $\begin{array}{l}422 \pm 25,4 \\
940 \pm 29,1^{\mathrm{b}}\end{array}$ & $\begin{array}{l}47 \pm 6.09 \\
85 \pm 5.82^{\mathrm{b}}\end{array}$ \\
\hline
\end{tabular}

a Significance of the results, $\mathrm{p} \leq 0.05$ comparison of control

b Significance of the results, $\mathrm{p} \leq 0.001$ comparison of control

Data represent the mean (median) \pm SEM; $n=10$, and were analyzed with student t-test or Mann Whitney $U$ test . Abbreviations: C-control (untreated) group, B - (study group) rats were given paracetamol (acetaminophen) solution to drink by intra-oesophageal instillation in a dose of $2.4 \mathrm{~g} / \mathrm{kg}$ of body weight/24 hrs (i.e. $16 \mu \mathrm{mol} / \mathrm{kg}$ of body weight/24 hrs), after drinking it, they had unlimited access to distilled water.

Table 1: Activities of superoxide dismutase isoenzymes, glutathione peroxide se, glutathione-S- transferase and glutathione reductase in rat liver.

of time in rat liver. The experiment showed paracetamol- induced changes in the activities of antioxidative enzyme in comparison to the control values (Table 1).

The activity of MnSOD in the rats administered with paracetamol was decreased when compared to the control values. The decreases were statistically significant at 8 and 12 weeks of exposure and insignificant at 4 weeks. The most pronounced decreases in MnSOD activity were observed after 8 and 12 weeks of PC administration, when compared to the enzyme activity after 4 weeks.

The activity of $\mathrm{Cu} / \mathrm{ZnSOD}$ showed a statistically significant decrease at 4 and 12 weeks of exposure to acetaminophen. At 8 weeks, there was a non-significant increase in $\mathrm{Cu} / \mathrm{ZnSOD}$ activity compared to control values.

The activity of GPX decreased in all groups exposed to paracetamol, when compared to controls. The decrease was statistically insignificant at 4 weeks and significant at 8 and 12 weeks. The greatest decreases in glutathione peroxidase activities were observed at 8 weeks and 12 weeks compared to the values in the 4 -week study and control groups.

The activity of GST showed an increase in all study groups compared to controls. The increase at 4,8 as well as 12 weeks were statistically significant. The greatest increase GST activity was observed

\begin{tabular}{|c|c|c|}
\hline Exposure time of PC & Groups & Means \pm SEM \\
\hline 4 weeks & C & $2.0 \pm 0.152$ \\
& B & $2.12 \pm 0.555^{\mathrm{a}}$ \\
\hline 8 weeks & C & $2.23 \pm 0.787$ \\
\hline \multirow{2}{*}{12 weeks } & B & $3.15 \pm 0.443^{\mathrm{b}}$ \\
\hline & C & $2,55 \pm 0.199$ \\
\hline
\end{tabular}

a Significance of the results, $p \leq 0.05$ comparison of control

b Significance of the results, $p \leq 0.001$ comparison of control

Data represent the means $\pm S E M ; n=10$, and were analyzed with student t-test. Abbreviations: C-control (untreated) group, B - (study group) rats were given paracetamol (acetaminophen) solution to drink by intra-oesophageal instillation in a dose of $2.4 \mathrm{~g} / \mathrm{kg}$ of body weight $/ 24 \mathrm{hrs}$ (i.e. $16 \mu \mathrm{mol} / \mathrm{kg}$ of body weight $/ 24 \mathrm{hrs}$ ), after drinking it, they had unlimited access to distilled water.

Table 2: Malondialdehyde (MDA) concentration in rat liver. in the 12-week study group compared to the control group and the other study groups.

The activity of GR showed a statistically significant increase in all study groups when compared to controls. The greatest increase was noted in the 12-week group compared to the control as well as in the 4 and 8-weeks study groups.

Finally, changes in the concentration of MDA, as lipid peroxidation marker, are presented in Table 2. Exposure to paracetamol for 4, 8 and 12 weeks caused a statistically significant increase in MDA concentration in all study groups compared to controls. The highest concentrations were observed at 12 weeks in both study and control groups, while the lowest concentrations were observed in the 4-week group (groups: $\mathrm{C}$ and $\mathrm{B}$ ).

\section{Discussion}

Previous reports [15,22-25] have shown that the large dose of PC administration in the chronic manner resulted in the liver injury. Accordingly, PC had a negative influence upon liver metabolism by means of PC-protein adducts formation [26-29]. In our study we found clear-cut free radical-dependent mechanism of paracetamol toxic action influencing the rat liver after 8 and 12 weeks, when administered in a dose of $2.4 \mathrm{~g} / \mathrm{kg}$ of body weigth $/ 24 \mathrm{hrs}$, in a form of a potable solution.

In particular, $\mathrm{PC}$ has a negative influence upon liver metabolism and the PC-induced liver toxicity occurs by formation of PC-protein adducts [30]. One of the theories referring to hepatotoxic activity of paracetamol assumes that $\mathrm{N}$-acetyl-p-bensoquinone-imine can be a source of reactive oxygen species (ROS) [31]. Particularly reactive compounds are formed during alternative transformation of $a$ quinone NAPQI form into a hydroquinone form $[31,32]$. Free radicals, and particularly oxygen derivatives $\left(\mathrm{OH}^{*}\right)$ can cause injuries to proteins and membrane lipids as well as enzymatic proteins [33], ultimately resulting in the cell death. It has been shown that a large dose of paracetamol administered to rats causes a decrease in concentration of glutathione (GSH) in liver cells $[15,33]$. The mentioned paper suggests that toxicity of paracetamol depends on a balance between the rate of reactive PC metabolite (NAPQI) formation and regeneration of the reduced glutathione [11,33]. Increase of glutathione-S-transferase activity in the liver of rats administered with paracetamol (as found in 
Citation: Polaniak R, Bułdak RJ, Jacheć W, Helewski K, Wojnicz R, et al. (2011) Long-term Exposure to Acetaminophen is a Crucial for Activity of Selected Antioxidative Enzymes and Level of Lipid Peroxidation Process in Rat Liver. J Bioequiv Availab 3: 182-186. doi:10.4172/ jbb.1000082

our study), indirectly confirms the increase of NAPQI concentration in hepatocytes. This can also be confirmed by an increase in glutathione reductase activity - the enzyme which provides reduced glutathione, among others, for reactions catalysed by GST.

The concentration of malondialdehyde (MDA) as a marker of lipid peroxidation was not comparable in the tested and control groups throughout the tested period. This fact remains in concordance with the studies of Kaplowitz [34], though intensification of lipid peroxidation by paracetarnol seems to be dependent on the drug dose and an administration manner. Also, significant differences have been noted regarding to $\mathrm{Cu} / \mathrm{ZnSOD}$ and $\mathrm{MnSOD}$ activities as determined in the livers of rats that were given paracetamol, in comparison with the control group but not in all tested time period. Kyle et al. [35] obtained different test results, which suggest an increase in activity of superoxide dismutase (SOD) after PC treatment. The decrease in glutathione peroxidase activity, which was found in the 8 and 12 weeks of paracetamol administration, may be a result of toxic action of PC or its metabolites. Lipid peroxidation is one of the most vigorously investigated consequences of reactive oxygen species' (ROS) actions on membrane structure and function. One of the most abundant carbonyl products of lipid peroxidation is malondialdehyde (MDA), which also reacts with DNA to form adducts to deoxyguanosine, deoxyadenosine, and deoxycytidine [36]. GPX is an enzyme which does not only reduce hydrogen peroxide, but also organic superoxides. In such reactions, organic superoxide $(\mathrm{ROOH})$ becomes reduced to an appropriate alcohol ( $\mathrm{ROH})$. In the case of lipid superoxide, this means that it cannot become an initiator of lipid peroxidation and, therefore, glutatione peroxidase inhibits lipid peroxidation [37]. The results of our experiments with higher concentrations of MDA in the group treated with PC for 8 and 12 weeks are concordant with the low activity of the enzyme inhibiting lipid peroxidation process, glutatione peroxidase (GPX), in this group when compared to untreated controls. Lipid peroxidation appears to be the major source of endogenous DNA damage in hepatocytes that may contribute significantly to cancer. In the current study, long term treatment with PC increased the level of lipid peroxidation process and reduced activity of GPX in rat liver. We can conclude that Wistar rats exposed to PC for 8 or 12 weeks show decreased resistance toward exogenic $\mathrm{H}_{2} \mathrm{O}_{2}$ and higher oxidative stress in comparison to untreated controls due to decreased activity of GPX after PC treatment. Moreover, the value of MnSOD activity in groups of animals treated with paracetamol ( 4 and 8 weeks) were lower than activity of that enzyme in the control groups within the same time span. As the treatment time increased, the activity of the enzyme also grew after 8 weeks, when compared to the group which received paracetamol for 4 weeks only. However, after 12 weeks of paracetamol treatment, MnSOD activity decreased below the level obtained in the group of animals treated for the period of 8 and 4 weeks. The cause of that occurrence may be lack of efficient adaptation to oxidative stress in the mitochondria of the liver cells caused by a 12-week long absorption of the drug. Such a significant decrease of antioxidative activity of the mitochondria may cause increase of the superoxide radical anion concentration in that cell area, whereas the corresponding decrease of GPX activity in the same time frame may inhibit the rate of hydrogen peroxide dismutation. Increased superoxide radical anion and hydrogen peroxide concentration values, being Fenton's reaction substrates, result in an increase of concentration of toxic hydroxyl radicals. Furthermore, these radicals $\left(\mathrm{OH}^{*}\right)$ have sufficient energy to abstract hydrogen atoms from unsaturated lipids and so have the potential to directly initiate lipid peroxidation process [37]. During the research, we obtained significant increase of MDA concentration, which corresponds with lowered MnSOD and GPX activity after a 12week period of paracetamol treatment, when compared to groups (4 and 8 weeks of drug being administered) and corresponding control groups, which may confirm the hypothesis described above. However, Muller et al. [38] have found that activity of glutathione peroxidase increases under the influence of PC. Moreover, Qui-Ju et al. [33] studies consist a confirmation of a free radical-dependent mechanism of paracetamol toxic action, by showing the free radical-dependent mechanism as the effect of high PC doses. Chun et al. [30] showed that $\mathrm{N}$-acetylocysteine is the most effective drug for liver failure with PC hepatotoxicity. Ghanem et al. [39] present that PC pre-treatments were not toxic, as determined by markers of rat liver and serum.

The present study shows that paracetamol (PC) administration for 4 week used in overdose is a safe drug, however through cited literature and our findings suggest that excessive use of paracetamolcontaining pharmaceuticals can have a negative influence upon the liver metabolism. This suggests a need for further studies upon the paracetamol influence on human and animal organism. Metabolism disturbances in rat liver cells, which have resulted from paracetamol administration in conditions of our experiment, are the consequence of a free-radical-dependent mechanism.

\section{Aknowledgments}

This research was supported by the Silesian Medical University.

\section{References}

1. Bertolini A, Ferrari A, Ottani A, Guerzoni S, Tacchi R, et al. (2006) Paracetamol: new vistas of an old drug. CNS Drug Rev 12: 250-275.

2. Kim SN, Seo JY, Jung da W, Lee MY, Jung YS, et al. (2007) Induction of hepatic CYP2E1 by a subtoxic dose of acetaminophen in rats: increase in dichloromethane metabolism and carboxyhemoglobin elevation. Drug Metab Dispos 35: 1754-1758

3. Laine JE, Auriola S, Pasanen M, Juvonen RO (2009) Acetaminophen bioactivation by human cytochrome P450 enzymes and animal microsomes. Xenobiotica 39: 11-21

4. James LP, Mayeux PR, Hinson JA (2009) Acetaminophen-induced hepatotoxicity. Drug Metab Dispos 31: 1499-1506.

5. Reid AB, Kurten RC, McCullough SS, Brock RW, Hinson JA (2004) Mechanisms of acetaminophen-induced hepatotoxicity: role of oxidative stress and mitochondrial permeability transition in freshly isolated mouse hepatocytes J Pharmacol Exp Ther 312: 509-516.

6. Park BK, Kitteringham NR, Maggs JL, Pirmohamed M, Williams DP (2005) The role of metabolic activation in drug-induced hepatotoxicity. Annu Rev Pharmacol Toxicol 45: 177-202.

7. Kon K, Kim JS, Jaeschke H, Lemasters JJ (2004) Mitochondrial permeability transition in acetaminophen-induced necrosis and apoptosis of cultured mouse hepatocytes. Hepatology 40: 1170-1179.

8. Hinson JA, Reid AB, McCullough SS, James LP (2004) Acetaminopheninduced hepatotoxicity: role of metabolic activation, reactive oxygen/nitrogen species, and mitochondrial permeability transition. Drug Metab Rev 36: 805822.

9. Lawson JA, Farhood A, Hopper RD, Bajt ML, Jaeschke H (2000) The hepatic inflammatory response after acetaminophen overdose: role of neutrophils. Toxicol Sci 54: 509-516.

10. Koss G, Losekam M, Schuler F, Schreiber I (1991) The hepatic glutathione content and glutathione-S-transferase activity in the pike (Esox Lucius) and rat. Comp Biochem Physio 2: 257-258.

11. Tsikas D, Trettin A, Zörner AA, Gutzki FM (2011) In-source formation of $\mathrm{N}$-acetyl-p-benzoquinone imine (NAPQI), the putatively toxic acetaminophen (paracetamol) metabolite, after derivatization with pentafluorobenzyl bromide 
Citation: Polaniak R, Bułdak RJ, Jacheć W, Helewski K, Wojnicz R, et al. (2011) Long-term Exposure to Acetaminophen is a Crucial for Activity of Selected Antioxidative Enzymes and Level of Lipid Peroxidation Process in Rat Liver. J Bioequiv Availab 3: 182-186. doi:10.4172/ jbb.1000082

and GC-ECNICl-MS analysis. J Chromatogr B Analyt Technol Biomed Life Sci 879: $1476-1484$

12. Anderson BS, Rundgren M, Nelson SD, Harder S (1990) N-acetyl-pbenzoquinone imine - induced changes in the energy metabolism in hepatocyte. Chem Biol Interact 75: 201-211.

13. Van Miert, A.S.J.P.A.M (1986) The use in animals of drugs licensed for human use only. In: van Miert, A.S.J.P.A.M., Bogaert, MG, Debackere M. (Eds.)

14. Stroubelt O, Younest M (1992) The toxicological relevance of paracetamolinduced inhibition of hepatic respiration and ATP depletion. Biochem Pharmacol 44: $103-170$

15. Marotta F, Yadav H, Gumaste U, Helmy A, Jains S, et al. (2009) Protective effect of a phytocompound on oxidative stress and DNA fragmentation against paracetamol - induced live damage. Ann Hepatol 8: 50-56.

16. Oyanagui $Y$ (1984) Reevaulation of assay methods and estabilishment of kit for superoxide dismutase activity. Ana Jyt Biochem 142: 290-296.

17. Paglia D, Valentine M (1967) Studies on the quantitative and qualitative characterization of erytrocytes glutathione peroxidase. J Lab Clin Med 70: 158169.

18. Habig WH, Pabst MJ, Jakoby WB (1984) Glutathione S-transferases. J Bio Chem 249: 7130-7139.

19. Richterich R (1997) Oznaczanie aktywności reduktazy g1utationowej. Chem.K/ in PZWL 366-367.

20. Ohkawa H, Ohishi N, Kunio Y (1979) Assay for peroxides in animal tissues by thiobarbituric acid reaction. Anl Biochem 95: 351-358.

21. Lowry OH, Rosenbrought NJ, Farr AL, Randall RJ (1951) Protein measurement with the folin phenol reagent. J Bio Chem 193: 265-275.

22. Larson AM (2007) Acetaminophen hepatotoxicity. Clin Liver Dis 11: 525-548.

23. Davidson DG, Eastham WN (1966) Acute liver necrosis following overdose of paracetamol. British Med J 2: 497-499.

24. Eder H (1964) Chronic toxity studies on phenacetin, N-acetylo-p-aminopheno (NAPA) and acetylsalicylic on cats. Acta Pharmacol Toxic 21: 197-204.

25. Prescot LF (1983) Paracetamol, overdosage. Pharmacological considerations and management. Drugs 25: 290-314.

26. Adamson GM, Papadimitriou JM, Herman AW (1991) Postnatal micehave low susceptibility to paracetamol toxicity. Pediatr Res 29: 496-499.
27. Nazareth WM, Seth JK, McLean AE (1991) Effect of paracetamol on mitochondrial membrane function in rat liver slices. Biochem Pharm 42: 931 936.

28. O'Grady JG, Wendon J, Tan K (1983) Liver transplantation afterparacetamo overdose. Hepatology 3: 567-571.

29. Smolarek T, Higgins C, Amacher D (1990) Metabolism and cytotoxity of acetaminophen in hepatocytes cultures from rat, rabbit, dog and monkey. Drug Metab Dispos Biol Fate Chem 18: 659-663.

30. Chun LJ, Tong MJ, Busuttil, RW, Hiatt JR (2009) Acetaminophen hepatotoxicity and acute liver failure. J Clin Gastroenterol 43: 342-349.

31. Mason RP, Fischer V (1989) Free radicals of acetaminophen : their subsequent reactions and toxicological significance. Fed-Proc 45: 2493-2499.

32. van de Staat R, Vromans RN, Bosman P, de Vries J, Vermeulen NP (1988) Cytochrome P-450 mediated oxidation of substrates by electron-transfer, role of oxygen radicals and of I-and 2-electron oxidation of paracetamol. Chem Biol Interact 64: 267-280

33. Qui-Ju, L, Bessems JG, Commandeur LM (1994) Mechanism of protection of ebselen against paracetamol- induced toxicity in rat hepatocytes. Bioch Pharm 48: $1631-1640$

34. Kaplowitz N, Simon FR, Stolz A (1986) Drug induced hepatotoxicyty (clinical conference). An Intern Med 104: 826-839.

35. Kyle ME, Miccadei S, Nakae D (1987) Superoxide dismutase and catalase protect culture hepatocytes from the cytotoxity of acetaminophen. Biochem Biophys Res Commun 149: 889-896.

36. Peluso M, Srivatanakul P, Munnia A, Jedpiyawongse A, Ceppi M, et al. (2010) Malondialdehyde-deoxyguanosine adducts among workers of a Thai industria estate and nearby residents. Environ Health Perspect 118: 55-559.

37. Wiswedel I, Gardemann A, Storch A, Peter D, Schild L (2010) Degradation of phospholipids by oxidative stress--exceptional significance of cardiolipin. Free Radic Res 44: 135-145.

38. Muller A, Cadenas E, Graf P, Sies H (1984) A novel biologically active selenoorganic compound. Glutathione peroxidase - like activity in vitro and antioxidant capacity of ebselen (PZ 51). Biochem Pharmac 33: 3235-3239.

39. Ghanem CJ, Ruiz ML, Villnueva SS, Luquita M, Llesuy S, et al. (2009) Effect of repeated administration with subtoxic doses of acetaminophen to rats on entherohepatic reciculation of a subsequent toxic dose. Biochem Pharmacol 77: $1621-1628$. 